\title{
Equine fecal inoculum optimization in in vitro fermentation assays of dehydrated roughage
}

\section{Bruna Caroline Franzan ${ }^{1}$ (iD), Tatiana Werneck Franco ${ }^{2,6}$, Giselle Stefani ${ }^{2,6}$, Marcelo Maia Pereira $^{3}$, Fernando Queiroz de Almeida ${ }^{4}$, Vinicius Pimentel Silva ${ }^{5^{*}}$ (iD)}

\footnotetext{
1 Universidade Federal Rural do Rio de Janeiro, Programa de Pós-graduação em Zootecnia, Seropédica, RJ, Brasil.

2 Universidade Federal Rural do Rio de Janeiro, Seropédica, RJ, Brasil.

${ }^{3}$ Fundação Instituto de Pesca do Estado do Rio de Janeiro, Rio de Janeiro, RJ, Brasil.

${ }^{4}$ Universidade Federal Rural do Rio de Janeiro, Instituto de Veterinária, Departamento de Medicina e Cirurgia Veterinária, Seropédica, RJ, Brasil.

${ }^{5}$ Universidade Federal Rural do Rio de Janeiro, Instituto de Zootecnia, Departamento de Nutrição Animal e Pastagens, Seropédica, RJ, Brasil.

${ }^{6}$ Scientific initiation fellow.
}

\begin{abstract}
This study evaluated the influence of coastcross hay substrate hydration and equine fecal inoculum dilution on the parameters of fermentation and microbiology in in vitro essays. A $2 \times 2$ factorial block design was used. The first factor was hydration of the coastcross hay substrate $12 \mathrm{~h}$ before incubation or at the time of incubation, and the second factor was the dilution of fecal inoculum with a nutrient solution in a weight: weight ratio of 1:1 or 1:3. Degradation of the dry matter (DM), organic matter (OM), and neutral detergent fiber (NDF) were evaluated at 24, 48, and $72 \mathrm{~h}$. Microorganisms were counted $24 \mathrm{~h}$ after inoculation. The ammoniacal nitrogen concentration $\left(\mathrm{NH}_{3}-\mathrm{N}\right), \mathrm{pH}$, and cumulative gas production were measured up to $72 \mathrm{~h}$ and adjusted by the non-linear Gompertz regression model. Hydration of substrate and time of incubation increased nutrient degradation of coastcross hay, as well as the final volume of gases and the concentration of Streptococcus spp. The 1:3 dilution increased the final $\mathrm{pH}$ and Streptococcus spp. concentration. The hydration of substrate did not have any effect on $\mathrm{NH}_{3}-\mathrm{N}_{\text {, }}$ Lactobacillus spp., cellulolytic, and total anaerobic bacteria concentrations. In addition, no effect of hydration was observed on the fermentation rate and the maximum fermentation time on the model used. The fermentation profile of the grass substrate is not affected by dilution, and, therefore, horse feces can be used as a source of inoculum in in vitro fermentation trials. Hydration increases the gas volumes and the nutrient degradation of grass hay, renders the lag phase time insignificant and, therefore, can be irrelevant in terms of fermentation model settings.
\end{abstract}

Key Words: degradation rate, gas production, microbiology, modeling, roughage

\section{Introduction}

The in vitro gas production technique is important to better understand horse nutrition, in which the diet effects on the activity of intestinal microbiota can be evaluated, and the nutrient degradation can be kinetically quantified without the need of fistulated animals (Murray et al., 2014), making it an important alternative to in vivo studies. Equine feces are easy to obtain and are mildly invasive.

However, some studies indicate that feces may present less fermentative capacity than other equine inoculum sources (Murray et al., 2014). There are differences in

Received: January 12, 2018

Accepted: April 8, 2018

*Corresponding author: pimentelzootec@gmail.com

Copyright (c) 2018 Sociedade Brasileira de Zootecnia. This is an Open Access article distributed under the terms of the Creative Commons Attribution License (http://creativecommons.org/licenses/by/4.0/), which permits unrestricted use, distribution, and reproduction in any medium, provided the original work is properly cited. fecal inoculation procedures in the in vitro tests: feces dilution (Elghandour et al., 2014) and substrate hydration (Rymer et al., 1999). The lack of standardization of fecal inoculum preparation generates differences in results and makes comparisons difficult, impairing the technique.

Mathematical modelling assists in the interpretation of the in vitro fermentation kinetics studies, which provides a dynamic approach applied to the model parameters (Mould et al., 2005). The mathematical models for gas production applied to equine studies were originally from research on ruminants (Groot et al., 1996).

There are anatomical differences between ruminant and equine species; therefore, some essential characteristics of the substrate that will be fermented must be considered (Sunvold et al., 1995), such as the substrate already predigested and hydrated when the first contact with the microorganisms occurs in the cecum. Such conditions play an important role in the substrate recognition 
time, consequently, on the estimates of fermentation model parameters that will be influenced. There is no standardized protocol for the use of equine feces as a source of inoculum in gas production trials, and there is also a lack of fermentative studies with microbiological evaluation using fecal inoculum.

The objective of this study was to evaluate the influence of hay hydration and the equine feces dilution on in vitro fermentation parameters and microbial population.

\section{Material and Methods}

The experiment was carried out in Seropédica, Rio de Janeiro, Brazil $\left(22^{\circ} 45^{\prime} 52.7^{\prime \prime} \mathrm{S}, 43^{\circ} 41^{\prime} 22.4^{\prime \prime} \mathrm{W}\right.$, and $33 \mathrm{~m}$ altitude). Research on animals was conducted according to the institutional committee on animal use registered under case no. 2015/002590.

The feces from three stallions of Mangalarga Marchador breed were used to provide the fecal samples, and the coastcross hay provided for feeding the animals was used as a substrate in the in vitro fermentation essays throughout the experimental period.

A $2 \times 2$ factorial block design was used. The first factor was hydration of the substrate $12 \mathrm{~h}$ before incubation and at the time of incubation. The second factor was dilution of the feces (inoculum) with a nutrient solution in a weight:weight ratio of $1: 1$ or $1: 3$. The cumulative gas production and nutrient degradation were analyzed in a randomized block design with repeated measures over time. The test was repeated for five consecutive weeks, each week being an experimental block.

The horses with an average body weight of $400 \mathrm{~kg}$, which had been previously dewormed with ivermectin (Eqvalan Golden ${ }^{\circledR}$, Merial), were kept in individual stalls with a feeder and water ad libitum and exercised three times a week for $30 \mathrm{~min}$. The diet of the horses was composed of coastcross hay (Cynodon spp. cv coastcross), mineral salt (Essencefós ${ }^{\circledR}$, Presence), water ad libitum, and concentrate meal (Table 1) provided at 07:00 and 16:00 h. The average dry matter intake of the diet was $26 \mathrm{~g} \mathrm{~kg}^{-1}$ of liveweight in the ratio of 66:34 of roughage:concentrate.
The coastcross hay and concentrate meal samples were milled to $1-\mathrm{mm}$ sieve in a Willey mill. The analysis performed were of dry matter, crude protein, and ash (AOAC, 1995), and ether extract and crude energy (Silva and Queiroz, 2006). The neutral detergent fiber (NDF) (Van Soest et al., 1991) and lignin were analyzed by oxidation of lignin with permanganate (Van Soest and Robertson, 1980).

The gas production incubations were perfomed as follows: feces were collected simultaneously from the rectum of horses at 09:00 h, two hours after the meal. The fecal samples were kept closed in preheated thermal bottles until processing in the laboratory. The time elapsed between the collection of feces and preparation of the inoculum in the laboratory was $20 \mathrm{~min}$.

The fermentation test protocol required the insertion of $1 \mathrm{~g}$ of hay milled to $2 \mathrm{~mm}$ into $160 \mathrm{~mL}$ flasks, plus $90 \mathrm{~mL}$ of nutrient solution (Theodorou et al., 1994). The nutrient solution was added $12 \mathrm{~h}$ before and at the moment of inoculation, constituting, therefore, the procedures adopted to perform the hydration treatment. The flasks that had been hydrated for $12 \mathrm{~h}$ were kept under refrigeration at $4{ }^{\circ} \mathrm{C}$ and, $2 \mathrm{~h}$ before inoculation, they were heated in a water bath at $39^{\circ} \mathrm{C}$.

The procedude adopted to prepare the fecal inoculum were: the fecal samples from three animals were proportionally mixed, then divided into two fractions - the first was diluted with nutrient solution at a ratio of 1:1 (w:w) and the second diluted with nutrient solution at the ratio of 1:3 (w:w). The diluted feces were then shaken for $1 \mathrm{~min}$ in a blender, after which they were placed in a water bath at $39{ }^{\circ} \mathrm{C}$ under constant spraying with $\mathrm{CO}_{2}$ (Desrousseaux et al., 2012). After $1 \mathrm{~h}$, the feces diluted with nutritive solution of each treatment were filtered through a $45-\mu \mathrm{m}$ nylon cloth to obtain two different inoculums (1:1 and 1:3). Finally, $10 \mathrm{~mL}$ of inoculum were added to bottles already prepared, and correspondent to the treatment described above, and sealed with rubber stoppers.

Fourteen flasks (replicates) were incubated for each treatment. After inoculation, the flasks were kept in a water bath at $39{ }^{\circ} \mathrm{C}$ with constant stirring. The gas production was measured manually by means of a pressure transducer

Table 1 - Chemical composition ( $\left.\mathrm{g} \mathrm{kg}^{-1} \mathrm{DM}\right)$ of concentrate (ground meal) and coastcross hay

\begin{tabular}{lcccccccccc}
\hline Nutrient & DM & MM & EE & CP & NDFom & ADF & Cel & Hem & Lig & NFC \\
\hline Concentrate & 885 & 109 & 47 & 231 & 165 & 73 & 50 & 92 & 21 & 456 \\
Coastcross hay & 888 & 84 & 25 & 139 & 737 & 359 & 283 & 38 & 53 & 15 \\
\hline
\end{tabular}

DM - dry matter; MM - mineral matter; EE - ether extract; ADF - acid detergent fiber; Cel - cellulose; Hem - hemicellulose; Lig - lignin determined by oxidation of lignin with permanganate; NFC - non-fibrous carbohydrates $(=100-(\mathrm{CP}+\mathrm{EE}+\mathrm{NDFom}+\mathrm{MM}) ; \mathrm{CP}$ - crude protein; NDFom - neutral detergent fiber not assayed with a heat stable amylase and expressed exclusive of residual ash. 
(LOGGER AG100, Universal Datalogger) at times: 1, 2, 3, $4,5,6,8,10,12,14,16,18,21,24,27,30,36,42,48,54$, 60,66 , and $72 \mathrm{~h}$, making a total of 23 readings. After each reading, accumulated gases were released and flasks were shaken. Pressure in psi was converted to volume per gram of dry matter using the specific equation for experimental conditions of gas production:

$$
\hat{y}=-0.07+3.79 x+0.077 x^{2}
$$

in which each psi corresponds to $3.80 \mathrm{~mL}$ (Martins, 2012).

The dry matter degradation (DMD), organic matter degradation (OMD), and neutral detergent fiber degradation expressed exclusive of residual ash (NDFD) were determined by the difference in nutrient weight present in the substrate before incubation and after 24, 48, and $72 \mathrm{~h}$ of fermentation. After $72 \mathrm{~h}$ of incubation, $\mathrm{pH}(\mathrm{pH} 300$; Analyzer ${ }^{\circledR}$ ) was recorded and $\mathrm{NH}_{3}-\mathrm{N}$ ammonia nitrogen $(\mathrm{mg} / \mathrm{dL})$ was evaluated after centrifugation at $10,000 \mathrm{~g}$ for $10 \mathrm{~min}$ at $4{ }^{\circ} \mathrm{C}$. Thereafter, $5 \mathrm{~mL}$ of the supernatant were pipetted and subjected to distillation and titration according to the micro-Kjeldahl method (Fenner, 1965; Souza et al., 2013).

Microorganisms were quantified $24 \mathrm{~h}$ after inoculation. The concentrations of total viable anaerobic bacteria were determined with complete modified agar medium (Leedle and Hespell, 1980) after $48 \mathrm{~h}$ of incubation at $39^{\circ} \mathrm{C}$ by the most-probable-number at $10^{-6}, 10^{-7}$, and $10^{-8}$ dilutions. The concentrations of cellulolytic bacteria were determined by the most-probable-number at $10^{-3}, 10^{-4}$, and $10^{-5}$ dilutions with modified (Halliwell and Bryant, 1963) liquid culture medium (Julliand et al., 1999) with readings taken after 15 days incubation at $39{ }^{\circ} \mathrm{C}$. The concentrations of Lactobacillus spp. and Streptococcus spp. were determined by counting colony forming units in Petri dishes prepared with MRS Lactobacillus base agar medium (200019, Biolog, Italy) and Azide Bile Esculine agar (06105-500g, Sigma-Aldrich, Buchs, Switzerland), respectively, in dilutions of $10^{-4}, 10^{-5}$, and $10^{-6}$ after $48 \mathrm{~h}$ of incubation at $39{ }^{\circ} \mathrm{C}$ in anaerobic jars.

The cumulative production of gases was adjusted using the nonlinear Gompertz equation (Winsor, 1932):

$$
V f=V m e^{-e^{-b\left(t-t^{*}\right)}}
$$

in which $V f=$ final volume of gases $(\mathrm{mL} / \mathrm{g} \mathrm{DM})$, estimated as a function of $\mathrm{Vm} ; \mathrm{Vm}=$ volume of gases at time $\mathrm{t}$ $(\mathrm{mL} / \mathrm{g} \mathrm{DM}) ; b=$ fermentation rate (mL/hour); $t^{*}=$ time (hours) when fermentation rate is maximum; and $t=$ time (hours). The estimated equation was used to calculate the fermentation rates $(\mathrm{mL} / \mathrm{g} \mathrm{DM})$ as a function of time $(\mathrm{t})$ by derivation of the Gompertz equation:

$$
d W t^{\prime} / d t=W m b e^{-b\left(t-t^{*}\right)-e^{-b\left(t-t^{*}\right)}}
$$

The NLIN procedure of the Statistical Analysis System, version 9.2 was used for parameter estimation. The parameter estimates were obtained by a modified iterative Gauss-Newton method developed by Hartley (1961) for nonlinear models. The distribution of the studentized residuals, used to detect discrepant points, in general, is considered as a marginally discrepant observation if $\left|\mathrm{Rti}^{*}\right|>3$ (Lemonte, 2008). The parameters of the models were compared using the likelihood ratio test (Regazzi, 2003).

The results from DMD, OMD, NDFD, $\mathrm{pH}, \mathrm{NH}_{3}-\mathrm{N}$, and the bacteriological count (logarithmic basis) were evaluated for the homoscedasticity of variances and normality. When the assumptions were met, they were subjected to ANOVA $(\alpha=0.05)$ and compared by the Fisher test $(\alpha=0.05)$. The analyses were carried out with the SISVAR statistical package (Ferreira, 2011).

\section{Results}

There was no interaction between the inoculum dilution and substrate hydration in nutrient degradation $(\mathrm{P}>0.05)$, but there was an effect of substrate hydration on DMD $(\mathrm{P}<0.05)$, OMD $(\mathrm{P}<0.05)$, and NDFD $(\mathrm{P}<0.05)$, and time $(\mathrm{P}<0.001)$ (Table 2$)$.

After adjusting the model, no effect of inoculum dilution on the parameters of the model was observed $(\mathrm{P}>0.05)$. However, the substrate hydration produced a significant effect on the final gas volume $(\mathrm{P}<0.001)$, but not on fermentation rate and time of maximum fermentation between both treatments of $12 \mathrm{~h}$ hydration before incubation or at the time of incubation (Table 3 ).

There was an effect of dilution factor on $\mathrm{pH}$ at the end of the fermentation $(\mathrm{P}<0.001)$, but no effects of hydration or interaction on $\mathrm{pH}$ were observed $(\mathrm{P}>0.05)$ (Table 4). However, there was no effect of treatments on $\mathrm{NH}_{3}-\mathrm{N}$ concentration of the fermentation residue after $72 \mathrm{~h}$ of incubation.

There was no effect of substrate hydration or inoculum dilution $(\mathrm{P}>0.05)$ on cellulolytic and total anaerobic Lactobacillus spp. bacteria concentration after $24 \mathrm{~h}$ of fermentation (Table 5). However, there was an effect of substrate hydration $(\mathrm{P}<0.05)$ and inoculum dilution $(\mathrm{P}<0.05)$ on the concentration of Streptococcus spp., but without significant interaction effect, with greater concentrations of microorganisms observed with the hydration starting at the moment of inoculation and with dilution 1:3. 


\section{Discussion}

No correction for soluble fraction on degradation of DM, NDF, and OM were performed. Pre-hydration of the substrate increased DMD, and, even disregarding the mineral fraction, this procedure increased OMD by approximately $10.2 \%$. Considering the total degradable substrate until $72 \mathrm{~h}$, the degradation extend reached 62.5 and $56.7 \%$ for DMD and OMD, respectively, after
$24 \mathrm{~h}$, showing that there was greater activity of fecal microorganisms at the beginning of the in vitro tests with the grass substrate.

In addition, there was an increase of NDFD when the substrate was pre-hydrated; consequently, different degradation profiles were observed for the treatment $0 \mathrm{~h}$ compared to $12 \mathrm{~h}$ of hydration. The relative difference observed between treatments at $24 \mathrm{~h}$ of degradation was approximately $30 \%$, reducing the observed difference a

Table 2 - Nutrient degradation $\left(\mathrm{mg} \mathrm{g}^{-1}\right)$ of coastcross hay hydrated for $12 \mathrm{~h}$ or immediately before inoculation with feces diluted in the ratios $1: 1$ and $1: 3$ up to $72 \mathrm{~h}(\mathrm{n}=60)$

\begin{tabular}{|c|c|c|c|c|c|c|c|}
\hline \multirow{2}{*}{ Nutrient degradation } & \multicolumn{6}{|c|}{ Time (h) } & \\
\hline & & 24 & 48 & 72 & Mean $^{5}$ & & \\
\hline \multirow[t]{8}{*}{ Dry matter $^{1}$} & Hydration & & & & & & \\
\hline & $12 \mathrm{~h}$ & 302 & 389 & 469 & $387 \mathrm{a}$ & & \\
\hline & $0 \mathrm{~h}$ & 268 & 360 & 442 & $356 b$ & & \\
\hline & Dilution & & & & & & \\
\hline & $1: 1$ & 283 & 380 & 465 & 376 & & \\
\hline & $1: 3$ & 286 & 368 & 446 & 367 & & \\
\hline & Time mean ${ }^{4}$ & $285 \mathrm{C}$ & 374B & $456 \mathrm{~A}$ & & & \\
\hline & Hydration (H) & Dilution (D) & Time $(\mathrm{T})$ & $\mathrm{H} \times \mathrm{D}$ & $\mathrm{T} \times \mathrm{H}$ & $\mathrm{T} \times \mathrm{D}$ & $\mathrm{T} \times \mathrm{H} \times \mathrm{D}$ \\
\hline P-value & 0.008 & 0.321 & 0.000 & 0.452 & 0.849 & 0.314 & 0.662 \\
\hline SEM & 6.08 & 6.08 & 2.78 & 8.61 & 7.32 & 7.32 & 10.35 \\
\hline \multirow[t]{8}{*}{ Organic matter ${ }^{2}$} & Hydration & & & & & & \\
\hline & $12 \mathrm{~h}$ & 257 & 345 & 433 & $345 \mathrm{a}$ & & \\
\hline & $0 \mathrm{~h}$ & 218 & 318 & 404 & $313 b$ & & \\
\hline & Dilution & & & & & & \\
\hline & $1: 1$ & 236 & 339 & 430 & 335 & & \\
\hline & $1: 3$ & 239 & 324 & 408 & 324 & & \\
\hline & Time mean ${ }^{4}$ & 237C & $332 \mathrm{~B}$ & $419 \mathrm{~A}$ & & & \\
\hline & Hydration & Dilution & Time & $\mathrm{H} \times \mathrm{D}$ & $\mathrm{T} \times \mathrm{H}$ & $\mathrm{T} \times \mathrm{D}$ & $\mathrm{T} \times \mathrm{H} \times \mathrm{D}$ \\
\hline P-value & 0.009 & 0.265 & 0.000 & 0.620 & 0.741 & 0.293 & 0.635 \\
\hline SEM & 6.67 & 6.67 & 3.57 & 9.43 & 8.19 & 8.19 & 11.58 \\
\hline \multirow[t]{8}{*}{ Neutral detergent fiber ${ }^{3}$} & Hydration & & & & & & \\
\hline & $12 \mathrm{~h}$ & 171 & 289 & 386 & $282 a$ & & \\
\hline & $0 \mathrm{~h}$ & 120 & 240 & 366 & $242 b$ & & \\
\hline & Dilution & & & & & & \\
\hline & $1: 1$ & 145 & 278 & 390 & 271 & & \\
\hline & $1: 3$ & 146 & 261 & 363 & 253 & & \\
\hline & Time mean ${ }^{4}$ & $146 \mathrm{C}$ & 264B & $376 \mathrm{~A}$ & & & \\
\hline & Hydration & Dilution & Time & $\mathrm{H} \times \mathrm{D}$ & $\mathrm{T} \times \mathrm{H}$ & $\mathrm{T} \times \mathrm{D}$ & $\mathrm{T} \times \mathrm{H} \times \mathrm{D}$ \\
\hline P-value & 0.025 & 0.269 & 0.000 & 0.540 & 0.311 & 0.327 & 0.528 \\
\hline SEM & 10.38 & 10.38 & 7.47 & 14.68 & 10.95 & 10.95 & 15.49 \\
\hline
\end{tabular}

SEM - standard error of the mean; CV - coefficient of variation; $\mathrm{H} \times \mathrm{D}$ - hydration and dilution interaction; $\mathrm{T} \times \mathrm{H}-$ time and hydration interaction; $\mathrm{T} \times \mathrm{D}-$ time and dilution interaction; $\mathrm{T} \times \mathrm{H} \times \mathrm{D}$ - time, hydration, and dilution interaction.

${ }^{1} \mathrm{CV} \%, 3.36$.

${ }^{2} \mathrm{CV} \%, 4.86$

${ }^{3} \mathrm{CV} \%, 12.76$

${ }^{4}$ Means with different letters within the row differ significantly $(\mathrm{P}<0.05)$ by the Fisher test.

${ }^{5}$ Means with different letters within the column differ significantly $(\mathrm{P}<0.05)$ by the Fisher test.

Table 3 - Parameters of the fermentation model with coastcross hay hydrated for 12 and $0 \mathrm{~h}$ before inoculation (mean \pm SEM)

\begin{tabular}{|c|c|c|c|}
\hline \multirow{2}{*}{ Parameter } & \multicolumn{2}{|c|}{ Hydration } & \multirow{2}{*}{ P-value } \\
\hline & $12 \mathrm{~h}$ & $0 \mathrm{~h}$ & \\
\hline Final volume of gases $\left(\mathrm{mL} \mathrm{g}^{-1} \mathrm{DM}\right)$ & $52.6 \pm 1.9$ & $39.1 \pm 1.4$ & 0.000 \\
\hline Fermentation rate $\left(\mathrm{mL} \mathrm{h}^{-1}\right)$ & $0.142 \pm 0.0143$ & $0.139 \pm 0.0142$ & 0.897 \\
\hline Maximum fermentation time (h) & $7.04 \pm 0.47$ & $8.29 \pm 0.48$ & 0.060 \\
\hline
\end{tabular}

SEM - standard error of the mean; DM - dry matter. 
Table 4 - Mean values of $\mathrm{pH}$ from the residual solution and ammoniacal nitrogen concentration $\left(\mathrm{mg} \mathrm{dL}^{-1}\right)$ after $72 \mathrm{~h}$ of coastcross hay fermentation under different hydration and dilution $(\mathrm{n}=20)$

\begin{tabular}{lcccc}
\hline & \multicolumn{4}{c}{ Hydration } \\
\cline { 2 - 5 } & Dilution & $12 \mathrm{~h}$ & $0 \mathrm{~h}$ & $\mathrm{Mean}^{3}$ \\
\hline $\mathrm{pH}^{1}$ & $1: 1$ & 6.53 & 6.55 & $6.54 \mathrm{~b}$ \\
& $1: 3$ & 6.62 & 6.65 & $6.64 \mathrm{a}$ \\
& Mean & 6.58 & 6.60 & \\
& Hydration (H) & Dilution (D) & $\mathrm{H} \times \mathrm{D}$ & \\
$\mathrm{P}-$ value & 0.060 & 0.000 & 0.685 & \\
$\mathrm{SEM}$ & 0.008 & 0.008 & 0.012 & \\
\hline $\mathrm{NH}_{3}-\mathrm{N}^{2}$ & $1: 1$ & 2.90 & 2.13 & 2.51 \\
& $1: 3$ & 2.70 & 2.27 & 2.48 \\
& Mean & 2.80 & 2.20 & \\
& Hydration & Dilution & $\mathrm{H} \times \mathrm{D}$ & \\
P-value & 0.272 & 0.955 & 0.750 & \\
SEM & 0.368 & 0.368 & 0.521 & \\
\hline
\end{tabular}

$\mathrm{H} \times \mathrm{D}$ - hydration and dilution interaction; SEM - standard error of the mean; CV coefficient of variation.

${ }^{1} \mathrm{CV} \%, 0.41$.

${ }^{2} \mathrm{CV} \%, 46.60$.

${ }^{3}$ Means with different letters differ significantly $(\mathrm{P}<0.05)$ by the Fisher test.

Table 5 - Concentration of Lactobacillus spp., Streptococcus spp., cellulolytic bacteria, and total anaerobes $\left(\log _{10} \mathrm{cfu} \mathrm{mL} \mathrm{m}^{-1}\right)$ of the residual solution after $24 \mathrm{~h}$ fermentation of coastcross hay subjected to different hydration and dilution $(\mathrm{n}=20)$

\begin{tabular}{|c|c|c|c|c|}
\hline & \multicolumn{4}{|c|}{ Hydration } \\
\hline & Dilution & $12 \mathrm{~h}$ & $0 \mathrm{~h}$ & Mean \\
\hline \multirow[t]{4}{*}{ Lactobacillus spp. } & $1: 1$ & 8.17 & 8.14 & 8.16 \\
\hline & $1: 3$ & 8.05 & 8.14 & 8.10 \\
\hline & Mean & 8.11 & 8.14 & \\
\hline & Hydration (H) & Dilution (D) & $\mathrm{H} \times \mathrm{D}$ & \\
\hline P-value & 0.617 & 0.375 & 0.347 & \\
\hline SEM & 0.0461 & 0.0461 & 0.0651 & \\
\hline \multirow[t]{4}{*}{ Streptococcus spp. ${ }^{1}$} & $1: 1$ & 7.61 & 7.90 & $7.76 \mathrm{a}$ \\
\hline & $1: 3$ & 7.93 & 7.97 & $7.95 \mathrm{~b}$ \\
\hline & Mean & $7.77 \mathrm{a}$ & $7.94 b$ & \\
\hline & Hydration & Dilution & $\mathrm{H} \times \mathrm{D}$ & \\
\hline P-value & 0.025 & 0.010 & 0.073 & \\
\hline SEM & 0.0458 & 0.0458 & 0.0648 & \\
\hline \multirow[t]{4}{*}{ Cellulolytic bacteria } & $1: 1$ & 3.78 & 3.72 & 3.75 \\
\hline & $1: 3$ & 4.08 & 3.97 & 4.02 \\
\hline & Mean & 3.93 & 3.84 & \\
\hline & Hydration & Dilution & $\mathrm{H} \times \mathrm{D}$ & \\
\hline P-value & 0.682 & 0.203 & 0.900 & \\
\hline SEM & 0.1425 & 0.1425 & 0.2016 & \\
\hline \multirow[t]{4}{*}{ Total anaerobes } & $1: 1$ & 6.53 & 6.67 & 6.60 \\
\hline & $1: 3$ & 6.45 & 6.44 & 6.44 \\
\hline & Mean & 6.49 & 6.56 & \\
\hline & Hydration & Dilution & $\mathrm{H} \times \mathrm{D}$ & \\
\hline P-value & 0.583 & 0.188 & 0.514 & \\
\hline SEM & 0.0800 & 0.0800 & 0.1132 & \\
\hline
\end{tabular}

$\mathrm{H} \times \mathrm{D}$ - hydration and dilution interaction; SEM - standard error of the mean.

${ }^{1}$ Means with different letters within the row or column differ significantly $(\mathrm{P}<0.05)$ by the Fisher test. long time; as observed at the end of $72 \mathrm{~h}$, this difference was reduced to $5.2 \%$. According to Julliand et al. (2001), microorganisms that degrade the plant cell wall are considered when quantifying cellulolytic bacteria. Although no difference was observed in the populations at $24 \mathrm{~h}$, maximum fermentation occurred between 7 and $8 \mathrm{~h}$ after incubation, indicating that this period is the best moment to observe differences in the cellulolytic community. At this time, gas production includes methane and $\mathrm{CO}_{2}$, which are derived from the substrate fermentation (Coles et al., 2005).

Hydration of the substrate speeds up the fermentation process at the initial incubation times; however, at this stage, only the gas production variable had been recorded. Even the fermentation prolonged up to $72 \mathrm{~h}$, nutrient degradation and final volume of gases were not compensated when equine feces were used as inoculum. According to Coles et al. (2005), the goal of an in vitro study is to represent in vivo events, adapting the physiological conditions of the species under study, such as $\mathrm{pH}$, temperature, incubation time, and so on.

Several studies with equine species were performed using in vivo or in situ methodologies to better understand the digestion process, which invariably involves kinetics of passage and nutrient degradation. Therefore, we have used the kinetic of passage (Van Weyenberg et al., 2006; Silva et al., 2014) and nutrient degradation information (Hyslop, 2006; Silva et al., 2010) to support the interpretations of the present study. Additionally, due to limitation to obtain fistulated animals for in vitro fermentation studies, a limiting factor nowadays, we had to use the information currently existing in the literature.

Therefore, Van Weyenberg et al. (2006) described values of mean retention time (MRT) in horses fed different feedstuffs no longer than $48 \mathrm{~h}$. Verifying the in situ degradation of nutrients of fibrous feed, Hyslop (2006) used the incubation up to $48 \mathrm{~h}$ as the maximum time for cecal incubation, and recently, Silva et al. (2014) fed fistulated horses coastcross hay with different particle size and observed values of $36.7 \mathrm{~h}$ of MRT. Consequently, the incubation time in in vitro fermentation essays with equine fecal inoculum should not exceed $48 \mathrm{~h}$.

According to Silva et al. (2010), who evaluated the in situ cecal degradation of nutrients in fistulated horses, a value of $34.3 \%$ NDFD of coastcross hay (Cynodon spp. cv coastcross) was observed after $48 \mathrm{~h}$ of incubation, which was greater than that observed in vitro in this study. The nutrient degradation depends on the fermentative activity and rate of digesta passage, which provides a constant supply of nutrients to microorganisms, maintaining the 
degradation activity of the bacteria on the fibrous substrate; this is a limiting element in in vitro techniques.

Total gas production is the sum of $\mathrm{H}_{2}, \mathrm{CO}_{2}$, and $\mathrm{CH}_{4}$ production along with in vitro incubation, and these gases are used as fermentative activity indicators in the hindgut of horses (Elghandour et al., 2016; 2018). Additionally, by quantifying the total gas production, it is possible to estimate the metabolizable energy and in vitro digestibility of organic matter (Menke et al., 1979) as well as the shortchain fatty acid concentration (Getachew et al., 2002). However, the procedures described above were developed with ruminal fluid studies but have been recently used in in vitro studies in equine nutrition (Elghandour et al., 2016; 2017 and 2018).

Rymer et al. (1999) identified that the gas production of the fibrous substrate increased after $6 \mathrm{~h}$ of hydration; however, $12 \mathrm{~h}$ were used in the present study to facilitate the semi-automatic experimental procedure.

The kinetics of gas production model developed for ruminant nutrition presents a sigmoid profile characterized by a lag phase followed by the exponential growth phase that slows down and reaches the asymptotic phase (Rymer et al., 2005; Vieira et al., 2008). As the fermentation profile of coastcross hay hydrated for $12 \mathrm{~h}$ presented a short lag phase and was not detectable by the model, the authors suggested that an exponential model that disregards the lag phase would be more adequate for equine studies, even using equine feces as inoculum.

According to Rymer et al. (1999), $6 \mathrm{~h}$ of hydration were sufficient to provide the soluble fraction from substrate into the medium, which does not change along the in vitro study period prior inoculation. Immediately after inoculation, the soluble nutrients are rapidly consumed; after that, the insoluble and potentially fermentable fraction of substrate will predominate. However, it needs to have been previously hydrated for the colonization of microorganisms (Groot et al., 1996). The initial development of the microorganisms present in the feces and the adhesion to the insoluble particles are time-dependent. Therefore, the hydration of coastcross hay facilitated adhesion to the substrate, optimizing the fermentation process. Murray et al. (2006) observed that lag phase time differences would occur depending on the chemical characteristics of the substrate, so that fibrous feedstuffs will present lag phases greater than the soluble substrates. However, they did not mention the hydration procedure on their protocol.

Coastcross is a $\mathrm{C}_{4}$ grass widely used in the tropics to feed horses and has a high lignification of the plant cell wall (Van Soest, 1994). Therefore, the 12-h hydration was fundamental to reduce the lag phase to $0.28 \mathrm{~h}$, allowing rapid access to the substrate by the fecal microbial community. Although we did not use the lag phase information for statistical comparisons, it was determinant in the choice and adjustment of the model. In addition, it made the in vitro procedures similar to what occurs naturally in vivo in the equine species.

The inoculum from equine feces may present a fermentation pattern similar to cecal inoculum, but it differs when compared to that of the colon (Murray et al., 2014). However, Julliand and Grimm (2016) reported that the fecal bacterial population was similar to that seen in the dorsal colon and lower colon. Thus, the production of gases may be more associated with the ability of the inoculum microorganisms to ferment a particular substrate than its concentration. In the present study, the same composite sample of feces diluted in 1:1 or 1:3 (weight:weight) was used, and the gas production appeared to be more influenced by the physical characteristics of the substrate than by the concentration of the fecal microorganisms. In addition, there was no difference in the concentration of microorganisms from the fecal inoculum of horses when collected at different times throughout the day; however, the gas production differed according to the substrates used (Desrousseaux et al., 2012). Therefore, the dilution of feces in the proportions used in the present in vitro fermentation assay can be used without affecting fermentation parameters of hay grasses and some microorganisms. In addition, the use of feces for the inoculum avoids the use of surgically modified or euthanized animals for collection of inoculum (Murray et al., 2014).

Cone et al. (1997) incubated glucose and observed an alteration in the fermentation profile after $45 \mathrm{~h}$, suggesting microbial turnover on in vitro fermentation systems. Additionally, these authors reported that the microbial protein was greater between 5 and $10 \mathrm{~h}$ of incubation, which coincided with the total intake of glucose, and the microbial protein was reduced after a prolonged period of fermentation with the formation of $\mathrm{NH}_{3}$. This suggests that the microbial nutrients were recycled, i.e., the development of new cells using dead cells as a nutrient source.

The microbial population present in the cecum uses non-protein $\mathrm{N}$ to generate volatile fatty acids (VFA) in detriment of population growth as a metabolic strategy (Santos et al., 2012). However, the quantification and identification of groups that would benefit from this nitrogen source were not carried out (Santos et al., 2012). The concentration of $\mathrm{NH}_{3}-\mathrm{N}$ in in vitro fermentation assays is inversely proportional to the concentration of microbial protein (Cone et al., 1997). In the present study, 
the $\mathrm{NH}_{3}-\mathrm{N}$ values observed after $72 \mathrm{~h}$ were greater than those observed by Santos et al. (2012), possibly due to the greater true protein fermentation present in the substrate.

The reduction of $\mathrm{pH}$ in in vitro studies is an indication of the accumulation of final fermentation products, such as VFA and lactate (De Fombelle et al., 2001; Coles et al., 2005) or the saturation of buffering agents in the medium. At the 1:3 dilution, there was a greater proportion of buffering agents from the nutrient solution in relation to the total number of microorganisms incubated. Therefore, for the fermentation products, the buffer was more effective as it left the solution less acidic compared to the 1:1 dilution. However, $\mathrm{pH}$ remained within the normal fermentation range (from 7.2 to 6.2) of large intestine for healthy horses (Clarke et al., 1990). The 1:3 dilution may be a strategy for in vitro studies in which there is an limited amount of feces to prepare the inoculum, such as in studies with new-born foals (Silva, 2017) ${ }^{1}$.

Although the $\mathrm{pH}$ was within clinical normality, the concentration of the genus Streptococcus spp., which is related to metabolism of rapidly fermenting carbohydrates, may have interfered with acidification (Julliand et al., 2001). The reduction of these nutrients caused by greater concentrations of microorganisms of the diluted 1:1 inoculum may have affected their growth. Besides, the hydration of the substrate also had an inhibitory effect on the growth of these microorganisms. Although the genus Streptococcus spp. is associated with the development of laminitis, they have a proteolytic and degradative activity of mono-, di-, and oligosaccharides of plant origin providing rapid access to these nutrient sources without relying on other microorganisms (Jans et al., 2015). However, a high concentration of Streptococcus leads to a reduction in the medium $\mathrm{pH}$, which may compromise the development of other important microorganisms in the fermentation of fibrous carbohydrates. Therefore, high concentrations of this microorganism are not desirable. Thus, treatments with lower dilution and greater hydration could offer a more balanced environment among the important bacterial populations.

The concentrations of Streptococcus observed in the present study were similar to those observed by Julliand et al. (2001) of $7.64 \log _{10} \mathrm{cfu} / \mathrm{mL}$ in the colon of fistulated horses fed a diet composed of $50 \%$ hay and $50 \%$ barley. When the diet ratio was changed to $70 \%$ hay and $30 \%$ barley, similar to the ratio of $66: 34$ (roughage:concentrate) used in the present study, the

\footnotetext{
${ }^{1}$ Silva, V. P. 2017. Personal communication. Universidade Federal Rural do Rio de Janeiro, Seropédica, RJ, Brasil.
}

authors observed concentrations of $6.84 \log _{10} \mathrm{cfu} / \mathrm{mL}$ in the colon. The concentrations of cellulolytic bacteria observed in the present study resemble that quantified by Julliand et al. (2001) of $4.78 \log _{10} \mathrm{cfu} / \mathrm{mL}$ in the cecum and colon of equines fed different proportions of barley, and this community is correlated with fiber utilization efficiency (Drogoul et al., 2001). In vitro studies have shown the concentration of cellulolytic bacteria of $5.11 \log _{10}$ $\mathrm{cfu} / \mathrm{mL}$ fecal inoculum from animals fed meadow hay and commercial concentrate (60:40) (Desrousseaux et al., 2012).

Assuming that the fecal inoculum was diluted three times as much in 1:3, consequently, there was an initial incubation of smaller amounts of microorganisms when compared with the population present in the 1:1 dilution, which suggests that there was a slower development of the bacterial population until $24 \mathrm{~h}$ when the 1:1 dilution was used. As a result, the microorganisms of the 1:3 inoculum developed rapidly due to the greater amount of nutrients available from the nutrient solution (Santos et al., 2011).

According to Bueno et al. (2005), the cellulolytic bacteria adhere to the solid particles of the inoculum and, therefore, with an increased solid phase in the incubation, are able to reduce the lag phase period of the fibrous substrates. In the present study, adjustments were made to the inoculum preparation protocol: feces were kept diluted in nutrient solution for $1 \mathrm{~h}$ in a water bath at $39^{\circ} \mathrm{C}$, under constant agitation and sprayed with $\mathrm{CO}_{2}$. This process aimed to increase the activity of cellulolytic bacteria present in the fecal inoculum.

Total anaerobes and Lactobacillus spp. values observed in the present study showed the same dilution factor as the concentrations of microorganisms observed by Julliand et al. (2001) and De Fombelle et al. (2001) in the colon of horses fed a diet with the same concentrate:roughage ratios as the horses of the present study.

The peak microbial growth was observed at approximately $10 \mathrm{~h}$ after incubation, when the cumulative gas production and nutrient degradation data were associated. However, the quantification of the microorganisms occurred at $24 \mathrm{~h}$, which was after the point of maximum bacterial development. Thus, in in vitro studies with fecal inoculum, the microbial community should be quantified in the exponential growth phase.

\section{Conclusions}

Dilution does not alter the fermentation profile of the roughage substrate. Therefore, this procedure does not limit the comparison between studies and allows the use of equine 
feces as source of inoculum for in vitro fermentation tests. The hydration of the substrate increases the fermentation process; thus, the lag phase time becomes insignificant and, therefore, can be irrelevant in terms of fermentation model settings. In addition, it increases the extent of substrate fermentation and nutrient degradation. Hydration of the substrate should be considered in in vitro fermentation test protocols for dehydrated roughage feedstuffs.

\section{Acknowledgments}

The manuscript is part of the dissertation of the first author presented to the Graduate Program in Animal Science of the Universidade Federal Rural do Rio de Janeiro and was financed in part by the Coordenação de Aperfeiçoamento de Pessoal de Nível Superior - Brasil (CAPES) - Finance Code 001.

\section{References}

AOAC - Association of Official Analytical Chemistry. 1995. Official methods of analysis. 16th ed. AOAC International, Arlington, VA.

Bueno, I. C.; Cabral Filho, S. L.; Gobbo, S. P.; Louvandini, H.; Vitti, D. M. and Abdalla, A. L. 2005. Influence of inoculum source in a gas production method. Animal Feed Science and Technology 123-124:95-105. https://doi.org/10.1016/j.anifeedsci.2005.05.003

Clarke, L. L.; Roberts, M. C. and Argenzio, R. A. 1990. Feeding and digestive problems in horses: Physiologic responses to a concentrated meal. The Veterinary Clinics of North America, Equine Practice 6:433-450.

Coles, L. T.; Moughan, P. J. and Darragh, A. J. 2005. In vitro digestion and fermentation methods, including gas production techniques, as applied to nutritive evaluation of foods in the hindgut of humans and other simple-stomached animals. Animal Feed Science and Technology 123:421-444. https://doi.org/10.1016/j.anifeedsci.2005.04.021

Cone, J. W.; Gelder, A. H. and Driehuis, F. 1997. Description of gas production profiles with a three-phasic model. Animal Feed Science and Technology 66:31-45. https://doi.org/10.1016/S0377-8401(96)01147-9

De Fombelle, A.; Julliand, V.; Drogoul, C. and Jacotot, E. 2001. Feeding and microbial disorders in horses: 1-Effects of an abrupt incorporation of two levels of barley in a hay diet on microbial profile and activities. Journal of Equine Veterinary Science 21:439-445. https://doi.org/10.1016/S0737-0806(01)70018-4

Desrousseaux, G.; Santos, A. S.; Pellikaan, W. F.; Van der Poel, A. F. B.; Cone, J. W. Guedes, C. M. V.; Ferreira, L. M. M. and Rodrigues, M. A. M. 2012. Effect of collection time on the fermentative activity of microbes in equine faeces. Animal Feed Science and Technology 178:183-189. https://doi.org/10.1016/j. anifeedsci.2012.09.016

Drogoul, C.; De Fombelle, A. and Julliand, V. 2001. Feeding and microbial disorders in horses: 2: effect of three hay: grain ratios on digesta passage rate and digestibility in ponies. Journal of Equine Veterinary Science 21:487-491. https://doi.org/10.1016/S0737-0806(01)70211-0

Elghandour, M. M. Y.; Cardenas-Chantres, J. C.; Esquivel-Velázquez, A.; Barbabosa-Pliego, A.; Cipriano, M. and Salem, A. Z. M. 2017.
In vitro cecal gas and methane production of soybean hullscontaining diets in the presence of Salix babylonica extract as a fermentation modulator in horses. Journal of Equine Veterinary Science 53:45-54. https://doi.org/10.1016/j.jevs.2016.12.004

Elghandour, M. M. Y.; Chagoyán, J. C. V.; Salem, A. Z. M.; Kholif, A. E.; Castañeda, J. S. M.; Camacho, L. M. and Buendía, G. 2014. In vitro fermentative capacity of equine faecal inocula of 9 fibrous forages in the presence of different doses of Saccharomyces cerevisiae. Journal of Equine Veterinary Science 34:619-625.

Elghandour, M. M. Y.; Kholif, A. E.; López, S.; Mendoza, G. D.; Odongo, N. E. and Salem, A. Z. M. 2016. In vitro gas, methane, and carbon dioxide productions of high fibrous diet incubated with fecal inocula from horses in response to the supplementation with different live yeast additives. Journal of Equine Veterinary Science 38:64-71. https://doi.org/10.1016/j.jevs.2015.12.010

Elghandour, M. M. Y.; Khusro, A.; Greiner, R.; Salem, A. Z. M.; de la Fuente, J. L.; Márquez-Molina, O.; Barbabosa-Pliego, A. and Jiménez, R. M. D. O. 2018. Horse fecal methane and carbon dioxide production and fermentation kinetics influenced by Lactobacillus farciminis: supplemented diet. Journal of Equine Veterinary Science 62:98-101. https://doi.org/10.1016/j.jevs.2017.12.006

Fenner, H. 1965. Method for determining total volatile bases in rumen fluid by steam distillation. Journal of Dairy Science 48:249-251. https://doi.org/10.3168/jds.S0022-0302(65)88206-6

Ferreira, D. F. 2011. Sisvar: a computer statistical analysis system. Ciência e Agrotecnologia 35:1039-1042. https://doi.org/10.1590/S1413-70542011000600001

Getachew, G.; Makkar, H. P. S. and Becker, K. 2002. Tropical browses: contents of phenolic compounds, in vitro gas production and stoichiometric relationship between short chain fatty acid and in vitro gas production. The Journal of Agricultural Science 139:341-352. https://doi.org/10.1017/S0021859602002393

Groot, J. C.; Cone, J. W.; Williams, B. A.; Debersaques, F. M. and Lantinga, E. A. 1996. Multiphasic analysis of gas production kinetics for in vitro fermentation of ruminant feeds. Animal Feed Science and Technology 64:77-89. https://doi.org/10.1016/S0377-8401(96)01012-7

Halliwell, G. and Bryant, M. 1963. The cellulolytic activity of pure culture strains of bacteria from the rumen of cattle. Journal of Genetic Microbiology 32:441-448.

Hartley, H. O. 1961. The modified Gauss Newton method for the fitting of non linear regression functions by least squares. Thechnometrics 3:269-280.

Hyslop, J. J. 2006. In situ and mobile bag methodology to measure the degradation profile of processed feeds in different segments of the equine digestive tract. Livestock Production Science 100:18-32. https://doi.org/10.1016/j.livprodsci.2005.11.007

Jans, C.; Meile, L.; Lacroix, C. and Stevens, M. J. 2015. Genomics, evolution, and molecular epidemiology of the Streptococcus bovis/Streptococcus equinus complex (SBSEC). Infection, Genetics and Evolution 33:419-436. https://doi.org/10.1016/j.meegid.2014.09.017

Julliand, V. and Grimm, P. 2016. The microbiome of the horse hindgut: History and current knowledge. Journal of Animal Science 94:2262-2274. https://doi.org/10.2527/jas.2015-0198

Julliand, V.; De Fombelle, A.; Drogoul, C. and Jacotot, E. 2001. Feeding and microbial disorders in horses: Part 3 - Effects of three hay: grain ratios on microbial profile and activities. Journal of Equine Veterinary Science 21:543-546. https://doi.org/10.1016/ S0737-0806(01)70159-1

Julliand, V.; Vaux, A.; Millet, L. and Fonty, G. 1999. Identification of Ruminococcus flavefaciens as the predominant cellulolytic bacterial species of the equine cecum. Applied and Environmental Microbiology 65:3738-3741. 
Leedle, J. A. Z. and Hespell, R. B. 1980. Differential carbohydrate media and anaerobic replica plating techniques in delineating carbohydrate-utilizing subgroups in rumen bacterial populations. Applied and Environmental Microbiology 39:709-719.

Lemonte, A. J. 2008. Diagnostic in normal linear regression: principle and applications. Biometric Brazilian Journal 26:7-26.

Martins, J. A. 2012. Suplementação dietética de equinos com eletrólitos. Dissertação (M.Sc). Universidade Federal Rural do Rio de Janeiro, Seropédica, RJ.

Menke, K. H.; Raab, L.; Salewski, A.; Steingass, H.; Fritz, D. and Schneider, W. 1979. The estimation of the digestibility and metabolizable energy content of ruminant feedingstuffs from the gas production when they are incubated with rumen liquor in vitro. The Journal of Agricultural Science 93:217-222. https://doi.org/10.1017/S0021859600086305

Mould, F. L.; Kliem, K. E.; Morgan, R. and Mauricio, R. M. 2005. In vitro microbial inoculum: a review of its function and properties. Animal Feed Science and Technology 123:31-50. https://doi.org/10.1016/j.anifeedsci.2005.04.028

Murray, J. M. D.; Longland, A. C.; Moore-Colyer, M. and Dunnett, C. 2006. The effect of feeding a low- or high-starch diet on the in vitro fermentative capacity of equine faecal inocula. Animal Science 82:627-635.

Murray, J. M. D.; McMullin, P.; Handel, I. and Hastie, P. M. 2014. Comparison of intestinal contents from different regions of the equine gastrointestinal tract as inocula for use in an in vitro gas production technique. Animal Feed Science and Technology 187:98-103. https://doi.org/10.1016/j.anifeedsci.2013.10.005

Regazzi, A. J. 2003. Teste para verificar a igualdade de parâmetros e a identidade de modelos de regressão não-linear. Revista Ceres 50:9-26.

Rymer, C.; Huntington, J. A.; Williams, B. A. and Givens, D. I. 2005. In vitro cumulative gas production techniques: history, methodological considerations and challenges. Animal Feed Science and Technology 123:9-30. https://doi.org/10.1016/j.anifeedsci.2005.04.055

Rymer, C.; Huntington, J. A. and Givens, D. I. 1999. Effects of inoculum preparation method and concentration, method of inoculation and pre-soaking the substrate on the gas production profile of high temperature dried grass. Animal Feed Science and Technology 78:199-213.

Santos, A. S.; Ferreira, L. M. M.; Martin-Rosset, W.; Cotovio, M.; Silva, F.; Bennett, R. N.; Cone, J. W.; Bessa, R. J. B. and Rodrigues, M. A. M. 2012. The influence of casein and urea as nitrogen sources on in vitro equine caecal fermentation. Animal 6:1096-1102. https://doi.org/10.1017/S1751731111002527

Santos, A. S.; Rodrigues, M. A. M.; Bessa, R. J. B.; Ferreira, L. M. and Martin-Rosset, W. 2011. Understanding the equine cecumcolon ecosystem: current knowledge and future perspectives. Animal 5:48-56. https://doi.org/10.1017/S1751731110001588
Silva, D. J. and Queiroz, A. C. 2006. Análise de alimentos: métodos químicos e biológicos. 3.ed. UFV, Imprensa Universitária, Viçosa, MG.

Silva, V. P.; Almeida, F. Q.; Morgado, E. S.; Rodrigues, L. M.; Santos, T. M. D. and Ventura, H. T. 2010. In situ caecal degradation of roughages in horses. Revista Brasileira de Zootecnia 39:349-355. https://doi.org/10.1590/S1516-35982010000200018

Silva, V. P.; Almeida, F. Q.; Pimentel, R. R. M.; Godoi, F. N.; Santos, T. M. D. and Pires, M. S. 2014. Passage kinetics of digesta in horses fed with coastcross hay ground to different degrees. Ciência e Agrotecnologia 38:506-514. https://doi.org/10.1590/S1413-70542014000500010

Souza, N. K. P.; Detmann, E.; Valadares Filho, S. C.; Costa, V. A. C.; Pina, D. S.; Gomes, D. I.; Queiroz, A. C. and Mantovani, H. C. 2013. Accuracy of the estimates of ammonia concentration in rumen fluid using different analytical methods. Arquivo Brasileiro de Medicina Veterinária e Zootecnia 65:17521758. https://doi.org/10.1590/S0102-09352013000600024

Sunvold, G. D.; Hussein, H. S.; Fahey, G. C.; Merchen, N. R. and Reinhart, G. A. 1995. In vitro fermentation of cellulose, beet pulp, citrus pulp, and citrus pectin using fecal inoculum from cats, dogs, horses, humans, and pigs and ruminal fluid from cattle. Journal of Animal Science 73:3639-3648. https://doi. org/10.2527/1995.73123639x

Theodorou, M. K.; Williams, B. A.; Dhanoa, M. S.; McAllan, A. B. and France, J. 1994. A simple gas production method using a pressure transducer to determine the fermentation kinetics of ruminant feeds. Animal Feed Science and Technology 48:185-197.

Van Soest, P. J. 1994. Nutritional ecology of the ruminant. Cornell University Press, Ithaca, NY.

Van Soest, P. J. and Robertson, J. B. 1980. Systems of analysis for evaluating fibrous feeds. p.49-60. In: Standardization of analytical methodology for feeds. Pigden, W. J.; Balch, C. C.; Graham, M., eds. IDRC, Ottawa, Canada.

Van Soest, P. J.; Robertson, J. B. and Lewis, B. A. 1991. Methods for dietary fiber, neutral detergent fiber, and nonstarch polysaccharides in relation to animal nutrition. Journal of Dairy Science 74:35833597. https://doi.org/10.3168/jds.S0022-0302(91)78551-2

Van Weyenberg, S.; Sales, J. and Janssens, G. P. J. 2006. Passage rate of digesta through the equine gastrointestinal tract: a review. Livestock Science 99:3-12. https://doi.org/10.1016/j. livprodsci.2005.04.008

Vieira, R. A. M.; Tedeschi, L. O. and Cannas, A. 2008. A generalized compartmental model to estimate the fibre mass in the ruminoreticulum: 1. Estimating parameters of digestion. Journal of Theoretical Biology 255:345-356. https://doi.org/10.1016/j.jtbi.2008.08.014

Winsor, C. P. 1932. The Gompertz curve as a growth curve Proceedings of the National Academy of Sciences 18:1-8. 